\title{
ARTICLES
}

Submitted 07.30.2020. Approved 03.09.2021

Evaluated through a double-blind review process. Scientific Editor: Henrique Correa

Original version | DOI: http://dx.doi.org/10.1590/So034-759020220106

\section{IS YOUR SUPPLY CHAIN READY FOR THE NEXT DISRUPTION? BUILDING RESILIENT CHAINS}

\author{
Sua cadeia de suprimentos está preparada para a próxima interrupção? Construindo cadeias resilientes \\ ¿Su cadena de suministro está preparada para la próxima disrupción? Construcción de cadenas \\ resilientes
}

Murilo Zamboni Alvarenga ${ }^{1}$ | murilozamboni@hotmail.com | ORCID: 0000-0002-4349-8262

Marcos Paulo Valadares de Oliveira1 ${ }^{1}$ marcos.p.oliveira@ufes.br | ORCID: 0000-0003-2646-5247

Hélio Zanquetto Filho' ${ }^{1}$ zanquetto@gmail.com | ORCID: 0000-0002-5693-0704

Kevin C. Desouza² | kevin.desouza@qut.edu.au | ORCID: 00oo-0002-4734-3081

Paula Santos Ceryno3 | paula.ceryno@unirio.br | ORCID: 0000-0001-8185-9092

${ }_{1}$ Universidade Federal do Espírito Santo, Programa de Pós-Graduação em Administração, Vitória, Espírito Santo, Brazil

${ }^{2}$ Queensland University of Technology, School of Management, Brisbane, Queensland, Australia

3Universidade Federal do Estado do Rio de Janeiro, Departamento de Engenharia de Produção, Rio de Janeiro, Rio de Janeiro, Brazil

\begin{abstract}
The ability to recover from disruptions is important for organizations and supply chains. Empirical data were used to investigate factors that affect supply chain recovery from disruptions, including collaboration, visibility, flexibility, analytical orientation, and supply chain risk management. A literature review was conducted to build an online questionnaire that was applied to manufacturing firms in Brazil. This work's statistical method includes confirmatory factor analysis and structural equation modeling. Our results indicate that a package of resilience capabilities - collaboration, flexibility, visibility, and analytical orientation - positively affect supply chain resilience. Improving such capabilities, therefore, will allow supply chains to recover better from disruptions. It was also discovered, however, that supply chains do not recover from disruptions by way of supply chain risk management alone. Mutual impacts also exist between the group of resilience capabilities and supply chain risk management.
\end{abstract}

KEYWORDS | Supply chain resilience, resilience capabilities, supply chain risk management, recovery, structural equation modeling.

RESUMO

A habilidade em se recuperar de interrupções é um importante fator para as organizações e suas cadeias de suprimentos. Dados empíricos foram utilizados para investigar fatores que impactam a recuperação das cadeias de suprimentos em face de interrupções, como a colaboração, visibilidade, flexibilidade, orientação analítica e a gestão de riscos. Uma revisão de literatura foi conduzida para desenvolver o questionário que foi aplicado em indústrias de transformação do Brasil. Os métodos estatísticos utilizados incluem a análise fatorial confirmatória e a modelagem de equações estruturais. Os resultados indicam que o pacote de capabilidades em resiliência - colaboração, flexibilidade, visibilidade e orientação analítica - impacta positivamente a resiliência das cadeias de suprimentos. Assim, aprimorar essas capabilidades permitirá uma recuperação mais adequada de interrupções. Também se constatou que a gestão de riscos, sozinha, não favorece a recuperação de interrupções. Adicionalmente, existe um impacto mútuo entre as capabilidades em resiliência e a gestão de riscos.

PALAVRAS-CHAVE / Resiliência em cadeias de suprimentos, capabilidades de resiliência, gestão de riscos, recuperação, modelagem de equações estruturais.

RESUMEN

La capacidad de recuperarse de las disrupciones es un factor importante para las organizaciones y sus cadenas de suministro. Se utilizaron datos empíricos para investigar los factores que afectan la recuperación de las cadenas de suministro ante disrupciones, como la colaboración, la visibilidad, la flexibilidad, la orientación analítica y la gestión de riesgos. Se realizó una revisión de la literatura para elaborar el cuestionario que se aplicó a las industrias manufactureras en Brasil. Los métodos estadísticos utilizados incluyen el análisis factorial confirmatorio y el modelado de ecuaciones estructurales. Los resultados indican que el paquete de capabilidades de resiliencia - colaboración, flexibilidad, visibilidad y orientación analítica- afecta positivamente la resiliencia de la cadena de suministro. Por lo tanto, mejorar estas capabilidades permitirá que las cadenas de suministro se recuperen más adecuadamente de las disrupciones. También se descubrió que la gestión de riesgos por sí sola no favorece la recuperación de las disrupciones. Además, existe un impacto mutuo entre las capacidades de resiliencia y la gestión de riesgos.

PALABRAS CLAVE / Resiliencia de la cadena de suministro, capabilidades de resiliencia, gestión de riesgos, recuperación, modelos de ecuaciones estructurales. 


\section{INTRODUCTION}

Examples such as COVID-19, which is impacting organizations and their supply chains around the world (Cosgrove, 2020); the departure of the UK from the European Union, which led to Domino's pizza spending US\$ 8.5 million on stocks of ingredients in the face of an increased risk of supply chain disruption (CNN, 2019); and the Phillips factory fire, which affected Ericsson's production (Norrman \& Jansson, 2004) demonstrate how risks and uncertainties can be devastating, not only for a single organization, but also for multiple supply chains members (Ambulkar, Blackhurst, \& Grawe, 2015).

Managers and scholars have been emphasizing, therefore, the need to build resilient supply chains to promote rapid recovery from disruptions (Brusset \& Teller, 2017; Pettit, Croxton, \& Fiksel, 2019). It is important to build resilient supply chains because of the interdependence of their members, with organizations both impacting and being impacted by internal or external disruptions. As supply chain members, therefore, organizations must develop their capabilities to become more resilient in order to help their supply chains return, to normal or improved operations after disruptions as quickly as possible, (Jüttner \& Maklan, 2011; Kwak, Seo, \& Mason, 2018; Pettit et al., 2019).

Some of the most extensively discussed resilience capabilities in literature up until 2016 were: collaboration (Jüttner \& Maklan, 2011; Pettit, Fiksel, \& Croxton, 2010; Scholten \& Schilder, 2015), flexibility (Jüttner \& Maklan, 2011; Ponomarov \& Holcomb, 2009; Sheffi \& Rice, 2005), and visibility (Brandon-Jones, Squire, Autry, \& Petersen, 2014; Christopher \& Peck, 2004; Scholten, Scott, \& Fynes, 2014; Wieland \& Wallenburg, 2013), and more recently, analytical orientation (Dubey et al., 2019; Ivanov, Dolgui, Das, \& Sokolov, 2019; Oliveira \& Handfield, 2019; Papadopoulos et al., 2017; Xu, Zhang, Feng, \& Yang, 2020).

Other quantitative studies investigated the relationship between these resilience capabilities and supply chain resilience on an individual basis: (i) flexibility (Brusset \& Teller, 2017; Mandal, Sarathy, Korasiga, Bhattacharya, \& Dastidar, 2016), (ii) collaboration (Kumar \& Anbanandam, 2019; Mandal et al., 2016), (iii) visibility (BrandonJones et al., 2014; Kumar \& Anbanandam, 2019; Mandal et al., 2016), and analytical orientation (Dubey et al., 2019; Singh \& Singh, 2019). We do not disagree that each capability has a positive influence on supply chain resilience, but our main argument is that these capabilities must act in synergy, and must be assembled into what we call a capability package, a single unit, that is important and needs to be in place in the supply chain as a whole. This argument is in line with Daugherty et al. (2006) and Scholten and Schilder (2015), since each capability is insufficient in itself and may sub-optimize the supply chain resilience results.

This research also presents an advance on the theoretical model first suggested by Alvarenga, Oliveira, Zanquetto-Filho and Santos (2018a), since we propose that there is a mutual impact between the package of resilience capabilities and supply chain risk management, and their joint impact on supply chain resilience. This research, therefore, aims to contribute by expanding knowledge about supply chain resilience and its antecedents based on a cycle of conceptual advances, empirical testing, and new conceptual advances (Colquitt \& ZapataPhelan, 2007).

In theory, although supply chain risk management is important for supply chain resilience, our main hypothesis here is based on the idea that the capabilities' package will have a greater positive impact. We believe that this logical and conceptual argument makes sense, and so besides proposing a theoretical model, we made an additional contribution by testing the model empirically.

From a practical point of view, if this hypothesis is true, supply chains must manage their resilient capabilities as a package, and not use each capability separately to increase their resilience. Considering the current and the 
future scenario, in which managers believe that disruptions will be more and more frequent, this would appear to be important for improving supply chain performance.

\section{THEORETICAL CONSTRUCTION OF THE HYPOTHESES}

\section{Supply chain resilience}

There is a lack of consensus about the definition of supply chain resilience, as evidenced by works by Ribeiro and Barbosa-Povoa (2018) and Wong, Lirn, Yang and Shang (2019). Views vary from those that consider supply chain resilience as being how to deal with an interruption and the subsequent moments, and those who also consider the moment before an interruption (Ali, Mahfouz, \& Arisha, 2017). We define supply chain resilience as the chain's ability to recover or move to a more desirable state after a disruption occurs (Brandon-Jones et al., 2014; Christopher \& Peck, 2004; Wong et al., 2019). So, in this paper, resilience is recovery. We argue that it is the resilience capabilities' package that enables the quickest return to operations (Brandon-Jones et al., 2014), or recovery from an unexpected risk event (Kwak et al., 2018). As a result, we adapted the indicators that Graeml and Peinado (2014) and Brandon-Jones et al. (2014) used to assess supply chain resilience.

According to Pettit, Fiksel, and Croxton (2010), supply chains must confront vulnerabilities by developing resilience capabilities, which are defined as the "attributes that enable the company to anticipate or recover from interruptions" (Pettit et al., 2010, p. 6). The capabilities that appear most often in supply chain resilience literature are collaboration (Jüttner \& Maklan, 2011; Pettit et al., 2010; Scholten \& Schilder, 2015), flexibility (Jüttner \& Maklan, 2011; Ponomarov \& Holcomb, 2009; Sheffi \& Rice, 2005), and visibility (Brandon-Jones et al., 2014; Christopher \& Peck, 2004; Scholten et al., 2014; Wieland \& Wallenburg, 2013).

\section{Package of resilience capabilities}

This section details the capabilities of the package we studied, with analytical orientation being noted as a particular resilience capability. We selected various capabilities using the Knowledge Development Process Constructivist (Proknow-C) methodology (Lacerda, Ensslin, \& Ensslin, 2012; Marafon, Ensslin, Lacerda, \& Ensslin, 2015). Based on 72 articles indexed on the Web of Science platform, or that appeared in Ebsco, Science Direct, and Emerald over the last 30 years, with titles containing the terms "supply chain resilience" or "resilient supply chain", we identified the most often cited papers, with 21 articles representing $90 \%$ of the citations on the topic. These papers and the most current papers that were compatible with the theme were used to build a foundation for the initial model.

\section{Collaboration}

Collaboration is defined as the relationship that exists between the supply chain's focal members and that enables joint strategies, information exchange, and knowledge sharing with its primary buyers and suppliers (Barratt, 2004; Cao \& Zhang, 2011).

Jüttner and Maklan's (2011) empirical study revealed that collaboration between chain members mitigates the negative impacts of disruptions. Furthermore, communication and cooperation between chain members has an impact on the resilience of the entire chain (Wieland \& Wallenburg, 2013) both statistically and significantly. 
Quantitative research enabled Kumar and Anbanandam (2019) and Mandal et al. (2016) to establish that collaboration has an impact on supply chain resilience.

The advantages of elements, such as collaboration, for building a resilient supply chain become clear during situations such as the financial collapse of freight carrier, Hanjin Shipping, in 2017 when its vessels were denied entry to ports around the world, and US\$14 billion in goods were abandoned. At the time, AGL Logistics, and its partner network, was able to find space for AGL customers' shipments with another carrier, which honored the original rate charged by Hanjin. Without that support, the business could have potentially waited months for clearance to dock in the United States (Roberson, 2019).

\section{Flexibility}

Supply chain flexibility relates to the chain members' ability to adjust their key processes - both internal and customer-oriented - by reacting or adapting to the environmental dynamics, and, consequently, delivering value to customers and guaranteeing the chain's profitability (Merschmann \& Thonemann, 2011; Swafford, Ghosh, \& Murthy, 2006, 2008). The construct in this research is operationalized as a reaction/adaptation capability in supply and delivery (Swafford et al., 2008).

A chain's flexibility enables a quick response when changes occur in supply and replenishment - such as a reduction in product development times - to then create a competitive advantage based on the chain's capacity to handle available resources, and its adaptive capacity (Sánchez \& Pérez, 2005; Merschmann \& Thonemann, 2011; Thomé, Scavarda, Pires, Ceryno, \& Klingebiel, 2014). The plan by H\&M’s CEO, Karl-Johan Persson, to improve performance results by moving from fast fashion to smart retailing, has meant that the retailer will have to build in operational resilience by creating a faster, more flexible, and technology-driven supply chain (Lopez, 2018).

Flexibility promotes resilience (Ojha, Ghadge, Tiwari, \& Bititci, 2018). To be considered resilient, the chain must develop the flexibility required to change either its inputs or outputs rapidly, or recognize how to bring about these changes. For example, such flexibility can be developed, among other things, by: cultivating multiple sources of supply and replenishment; developing contract flexibility; promoting risk-sharing; and improving inventory management (Pettit et al., 2010). A study of Brazil's automotive sector by Scavarda, Ceryno, Pires and Klingebiel (2015) also confirmed that flexibility results in resilience.

\section{Visibility}

Visibility is the capability that allows the focal company's visualization throughout the entire supply chain, and having a situational awareness of activity across the network and the environmental conditions in which the chain operates. More specifically, a firm can observe the inventory conditions of both its customers and suppliers (Christopher \& Peck, 2004), and avoid, for example, high “whip” effects.

From the focal company's perspective, the chain's visibility can be determined by understanding visibility as a capability that can be measured and that is influenced by the quantity and quality of the information exchanged. This favors the focal company, because it allows it to visualize inventory levels and their primary customers' and suppliers' demands precisely (Barratt \& Oke, 2007; Brandon-Jones et al., 2014; Caridi, Crippa, Perego, Sianesi, \& Tumino, 2010; Caridi, Perego, \& Tumino, 2013). The visibility measures adopted here are based on indicators developed by Brandon-Jones et al. (2014). 
Visibility also involves a positive association with agility, or how fast the chain can recover from disruptions (Brandon-Jones et al., 2014; Christopher \& Peck, 2004; Namdar, Li, Sawhney, \& Pradhan, 2018). Brandon-Jones et al. (2014) first quantitatively verified the positive impact of visibility on supply chain resilience. Later, Kumar and Anbanandam (2019) and Mandal et al. (2016) stressed that visibility impacts supply chain resilience.

\section{Analytical orientation}

As noted by Ladeira et al. (2016), the analytical approach involves "the extensive use of critical data and explanatory and predictive models, as well as fact-based management to guide management decisions and actions” (p. 487). The members of analytically oriented chains efficiently process data through quantitative analyses to make factbased decisions regarding the chain's processes (Cao, Duan, \& Li, 2015; Souza, 2014).

Trkman, Mccormack, Oliveira and Ladeira (2010) empirically verified that the analytical approach to a supply chain's critical processes results in a better performance. Chae, Olson, and Sheu (2014) also verified that analytical chains have an impact on chain members' performance. More specifically, data can be used to produce insights into the context of organizational decision-making (Cao et al., 2015), which favors resilience by prevention, adaptation, and efficient decision-making for dealing with disruptions. Healthcare Ready, an organization that focuses on helping the pharmaceutical industry respond to natural disasters, is using inventory-tracking technology to support predictive analytics for pharmaceutical manufacturers and distributors in their preparations for dealing with different types of disaster (Wollenhaupt, 2019).

The definitions of analytical orientation in supply chains are closely related to the capacity for collecting and analyzing information and events in both internal and external environments. Digital twins, for example, are virtual representations of real objects that are designed to optimize the operation of assets and have a strong potential for helping supply chains improve their organizational resilience (Gartner highlights 'digital twins' as an emerging organizational resilience tool, 2018; Ivanov et al., 2019).

It is understood, therefore, that the generation, processing, storage, retrieval, sharing, and application of knowledge for decision making with regard to resilience are enhanced by the use of an analytical approach (Barbosa \& Vicente, 2018; Dubey et al., 2019; Ivanov et al., 2019). Consequently, the use of analytics can help with the recovery from disruptions (Dubey et al., 2019; Papadopoulos et al., 2017).

It is noteworthy that improving the set of capabilities enables improved resilience, even when considering each capability's impact on resilience, but, to the best of our knowledge, the joint impact of these capabilities has never been tested in the literature before. Based on these arguments, our first research hypothesis is:

H1: The resilience capabilities' package has a positive impact on supply chain resilience.

\section{Supply chain risk management}

Supply chain risk management (SCRM) involves identifying, assessing, and controlling the internal and external risks that may affect a chain's performance in order to eliminate or reduce the likelihood or impact of events that may disrupt the chain members' operations (Jüttner, Peck, \& Christopher, 2003; Sodhi, Son, \& Tang, 2012). The present study assumes that risks have to be jointly managed with chain members, and that efficient SCRM identifies, evaluates, controls, and monitors risks (Hallikas, Karvonen, Pulkkinen, Virolainen, \& Tuominen, 2004; Tummala \& Schoenherr, 2011). 
Recent studies indicate that a relationship exists between SCRM and a chain's resilience (Pavlov, Ivanov, Dolgui, \& Sokolov, 2018; Rajesh, 2017; Sáenz, Revilla, \& Acero, 2018), because SCRM strategies run parallel to resilience objectives (Namdar et al., 2018; Zineb, Brahim, \& Houdaifa, 2017). Still, Jüttner and Maklan (2011) argue that risk management provides environmental risk knowledge, thereby increasing the chain's resilience. Similarly, Colicchia, Dallari, and Melacini (2010) verified that adopting efficient risk management strategies for addressing lead-time variability also increases the chain's resilience.

If properly executed, SCRM not only reduces the vulnerabilities that may affect the organization's operations as a consequence of chain disruptions, but also prepares the organization in order to mitigate any possible risks (Norrman \& Jansson, 2004). Although this article assumes that a supply chain may recover with no need for prevention as it focuses on recovery as a dimension of resilience, scientific literature has found that SCRM may have an impact on supply chain resilience. This primarily involves preventing events that may interrupt its operations, while allowing actions to develop that can restore them (Ceryno, Scavarda, Klingebiel, \& Yüzgülec, 2013; Colicchia et al., 2010; Jüttner \& Maklan, 2011).

$\mathrm{H}$ 2: Supply chain risk management has a positive impact on supply chain resilience.

\section{Relationship between the package of resilience capabilities and supply chain risk management}

Risk management is also influenced by the capabilities that we addressed in previous sections. Efficient supply chain risk management involves collaborative management, flexibility, visibility, and being analytically oriented. Li, Fan, Lee and Cheng (2015) showed that the length of the relationship and trust strengthen the effectiveness of sharing risk information. Christopher and Peck (2004) pointed out that information exchange between supply chain members is a key priority for reducing risk. For more examples of the relationship between collaboration and SCRM, see Hernandez and Haddud (2018), Zineb et al. (2017), Prakash, Gautam and Soni (2018), and Durach and Machuca (2018). Studies showed that higher visibility promotes a better understanding of risks and how to mitigate them (Nooraie \& Parast, 2015; Prakash et al., 2018; Urciuoli \& Hintsa, 2018). Flexibility can be used to mitigate or avoid risk impacts by modifying inputs and outputs (Prakash et al., 2018; Sheffi \& Rice, 2005).

The opposite effect can also be identified in Jüttner and Maklan (2011) who concluded by way of a longitudinal case study with three supply chains that risk effect-oriented actions - considering risk sharing and hedging risks by way of redundant resources - has a positive impact on resilience capabilities in terms of flexibility, visibility and collaboration. SCRM helps reduce opportunistic behavior, enables loss dispersion, develops trust, allows disruptions to be absorbed by the parties, and reduces operational supply pipelines, thus reducing lead times (Jüttner \& Maklan, 2011).

Specifically with regard to SCRM and analytical capabilities, Tummala and Schoenherr (2011) argue that data management enables the gathering, storage, and retrieval of risk information, and consequently improves SCRM as a whole. Tang and Musa (2011) report that a quantitative approach to managing supply chain risks needs to be developed. On the one hand, the supply chain must develop a package of capabilities, as proposed in this study, for identifying, evaluating, and proposing mitigation strategies for managing risks properly (Alvarenga, Oliveira, Zanquetto-Filho, \& Santos, 2018b), which includes the need for an analytical orientation to efficiently identify 
and measure risks, thus facilitating their proper management (Ittmann, 2015; Pettit et al., 2019). On the other, risk management can provide supply chain members with useful data, and improve their analytical orientation.

Only the individual relationships of these capabilities and supply chain risk management were tested in the literature. Here we are interested in the package of these capabilities, not in each impact, so the third research hypothesis is:

H3: A positive, mutual relationship exists between the resilience capabilities' package and supply chain risk management.

\section{METHODOLOGY}

Data were collected from August to December 2017, using an online three-block questionnaire, which was presented randomly, using a seven-point Likert-type scale from one (totally disagree) to seven (totally agree). After developing the questionnaire, we pre-tested it with ten manufacturing or supply chain management managers from manufacturing firms. Following the procedures, the questionnaire was then sent to all manufacturing organizations listed in the Federation of Industries of Minas Gerais, São Paulo, Rio de Janeiro, and Espírito Santo. Companies from Minas Gerais were contacted through the Industrial and Business Center of Minas Gerais (CIEMG), while the others through the Brazilian Publisher of Special Guides (EBGE).

The final sample had 143 complete answers from 151 in total. Using $G^{*}$ Power software, the necessary sample size was calculated based on two predictor constructs (the resilience capabilities' package and risk management), setting 0.15 as the effect size, a test power of 0.80 , and 0.05 as the error probability. The minimum sample size found was 43 cases. The same software was used post hoc to calculate the ideal test power given the sample size that was obtained, and it reached an explanatory power of $99.84 \%$.

The structural equation modeling analysis was processed using Smart-PLS software (Ringle, Wende, \& Becker, 2014). According to Hair et al. (2009), structural equation modeling provides the possibility of efficiently estimating a series of separate multiple regression equations, which can all be simultaneously calculated by considering the relationships between the manifested variables and their constructs.

\section{DATA ANALYSIS AND RESULTS}

\section{Sample description}

We used number of employees to check the size of companies since, in Brazil, it is difficult to use a firm's gross revenue. Therefore, we used only this criterion. Organizations with up to 19 employees were considered to be micro-firms, those with 19 to 99 employees were considered to be small, with 100 to 499 employees were considered to be medium/average, while firms with more than 499 employees were considered to be large. See Table 1. According to the Brazilian Micro and Small Business Support Service (SEBRAE, 2016) yearbook, 98\% of Brazilian manufacturing firms are micro or small. Our sample has $77 \%$ micro or small, and more medium-sized firms. Therefore, we carried out a heterogeneity test using company size for improving the reliability of our sample and improving the consistency of the results. 
Table 1. Sample description

\begin{tabular}{c|c|c|c|c|c|c|c|c}
\hline \multicolumn{2}{c|}{ Organizations' Employees } & \multicolumn{2}{c|}{ Respondent's positions } & \multicolumn{3}{c}{ Main functions } \\
\hline Category & Quantity & $\%$ & Category & Quantity & $\%$ & Category & Quantity & $\%$ \\
\hline$<19$ & 54 & 37.80 & Chairmen & 19 & 13.30 & Manufacturing & 62 & 43 \\
\hline $19-99$ & 56 & 39.20 & Company officers & 46 & 32.20 & Purchasing & 34 & 24 \\
\hline $100-499$ & 28 & 19.6 & Managers & 58 & 40.60 & Marketing/Sales & 17 & 12 \\
\hline$>500$ & 5 & 3.5 & Assistants & 8 & 5.60 & Other & 30 & 21 \\
\hline & & & Other & 12 & 8.40 & & & \\
\hline
\end{tabular}

\section{Measurement model}

An analysis of the constructs' internal reliability revealed that the composite reliability values were in accordance with the limits stipulated by Hair, Hult, Ringle and Sarstedt (2017), which is greater than 0.7 and less than 0.95. Regarding convergent validity - or how the indicators correlate with the other indicators in the same construct (Hair et al., 2017) - the outer loadings obtained values greater than 0.703 , except for the R3 variable. Although this variable outer loading is below the cut-off point, it was considered acceptable (above 0.4) since it was both statistically significant, and exclusion would not guarantee a substantial improvement in the measurement model. Average variance extracted (AVE) also had acceptable values, greater than 0.5. The questionnaire and measurement results are shown in Table 2 below.

\section{Table 2. Questionnaire and measurement results}

Regarding your supply chain (your organization, main customers, and main suppliers):

\section{Analytical orientation - Composite reliability $=0.87$, Average variance extracted $=0.70$.}

A1 - The quantitative analysis of data directs managerial actions. (Load - 0.767)

A2 - Members use the knowledge generated from quantitative data analysis to improve chain processes. (Load - 0.879)

A3 - To support management decisions, members can process data efficiently. (Load - o.866)

Collaboration - Composite reliability $=\mathbf{0 . 8 8}$, Average variance extracted $=\mathbf{0 . 7 1}$.

C1 - Members' opinions are generally used to improve supply processes. (Load - 0.735)

C2 - Members effectively communicate changes in their supply processes. (Load - 0.894)

C3 - Members execute plans to improve supply processes jointly. (Load - 0.891)

Flexibility - Composite reliability $=0.84$, Average variance extracted $=0.64$.

F1 - When necessary, members can modify the production volume capacity. (Load - 0.838)

F2 - When necessary, members can accommodate changes in the production mix. (variety of products). (Load - o.835)

F3 - When necessary, members can reduce production time. (Load - 0.733)

Visibility - Composite reliability $=0.83$, Average variance extracted $=0.63$. 
Regarding your supply chain (your organization, main customers, and main suppliers):

V1 - Can accurately see information about customer demand levels. (Load - 0.807)

V2 - Can accurately view information about customer stock levels. (Load - 0.856)

V3 - Can accurately view information about vendor stock levels. (Load - 0.714)

Supply chain risk management - Composite reliability $=0.92$, Average variance extracted $=0.74$.

S1 - It has formal processes to identify risks. (Load - 0.799)

S2 - Can minimize the impact of risks. (Load - 0.838)

S3 - Risks are often assessed by members of the chain. (Load - 0.919)

S4 - Risks are often monitored by members of the chain. (Load - 0.891)

Supply chain resilience - Composite reliability $=0.81$, Average variance extracted $=0.60$.

R1 - Can quickly recover material flow in case of interruptions. (Load - 0.845)

R2 - Can easily return to its original state in case of interruptions. (Load - 0.856)

R3 - Can develop useful knowledge from interruptions. (Load - 0.603)

Discriminant validity was verified using the Fornell-Lacker analysis (Table 3). The purpose was to verify whether the respondents perceived the study's constructs differently (Hair et al., 2017). We subsequently observed that the square-root of the construct's AVE is greater than the construct's correlation with the model's other constructs. The results demonstrate that the constructs can be considered unique, and each construct is capturing a different phenomenon.

Table 3. Fornell-Lacker analysis

\begin{tabular}{l|c|c|c|c|c|c}
\hline Construct & Collaboration & Flexibility & SCRM & $\begin{array}{c}\text { Analytical } \\
\text { orientation }\end{array}$ & SCRES & Visibility \\
\hline Collaboration & $\mathbf{0 . 8 4 3}$ & & & & & \\
\hline Flexibility & 0.549 & $\mathbf{0 . 8 0 3}$ & & & & \\
\hline SCRM & 0.458 & 0.325 & $\mathbf{0 . 8 6 3}$ & & & \\
\hline $\begin{array}{l}\text { Analytical } \\
\text { orientation }\end{array}$ & 0.570 & 0.358 & 0.556 & $\mathbf{0 . 8 3 9}$ & & \\
\hline SCRES & 0.350 & 0.379 & 0.294 & 0.133 & $\mathbf{0 . 7 7 7}$ & \\
\hline Visibility & 0.304 & 0.192 & 0.263 & 0.341 & 0.231 & 0.794 \\
\hline
\end{tabular}

\section{Hierarchical model results}

The model results after executing a bootstrapping procedure with 5,000 subsamples (Table 4) statistically confirm that collaboration, flexibility, visibility, and analytical orientation are components of the resilience capabilities' package, as all p-values were less than 0.05 , thus corroborating previous theoretically developed arguments. We can observe that the collaboration capability has demonstrated the greatest relevance in package of resilience capabilities formation, followed by analytical orientation. 
Table 4. Second-Order construct measurement model

\begin{tabular}{|c|c|c|c|c|}
\hline \multirow{3}{*}{ Latent Variable (Second-Order) } & \multirow{3}{*}{ First-Order Construct } & \multirow{2}{*}{$\begin{array}{c}\text { Collinearity } \\
\text { VIF }\end{array}$} & \multicolumn{2}{|c|}{$\begin{array}{l}\text { Indicators' Significance } \\
\text { and Relevance }\end{array}$} \\
\hline & & & Weight & $p$-value \\
\hline & & $<5$ & - & $<0.05$ \\
\hline \multirow{4}{*}{$\begin{array}{l}\text { Package of Resilience } \\
\text { Capabilities }\end{array}$} & Collaboration & 1.884 & 0.421 & $5.684 \mathrm{E}-14$ \\
\hline & Flexibility & 1.437 & 0.336 & $5.684 \mathrm{E}-14$ \\
\hline & Visibility & 1.155 & 0.234 & $5.684 \mathrm{E}-14$ \\
\hline & Analytical Orientation & 1.559 & 0.337 & $6.859 \mathrm{E}-08$ \\
\hline
\end{tabular}

\section{Structural model}

The structural model was assessed by inspecting each regression's results. As it is not possible to test a two-handed arrow in SmartPLS, the mutual relationships were determined by testing the Pearson correlation coefficient against the latent variable scores. After executing a bootstrapping procedure with 5,000 subsamples, and the Pearson correlation test, Figure 1 illustrates the model's results, with the numbers in parentheses delineating the relationship a. It should be noted that no collinearity exists between the predictive constructs, as the variance inflation factor was 1.455 .

The path coefficient values and a confirm Hypotheses $\mathrm{H}_{1}$ and $\mathrm{H}_{3}$. Hypothesis $\mathrm{H}_{2}$, however, was rejected. The results also demonstrate that $15.22 \%$ of the variation in supply chain resilience comes from variations in the resilience capabilities' package and SCRM. Although this can be interpreted as weak, it is significant, and it is relevant that there are many other factors that the present study did not address that may also have an impact on supply chain resilience.

Figure 1. The proposed model results

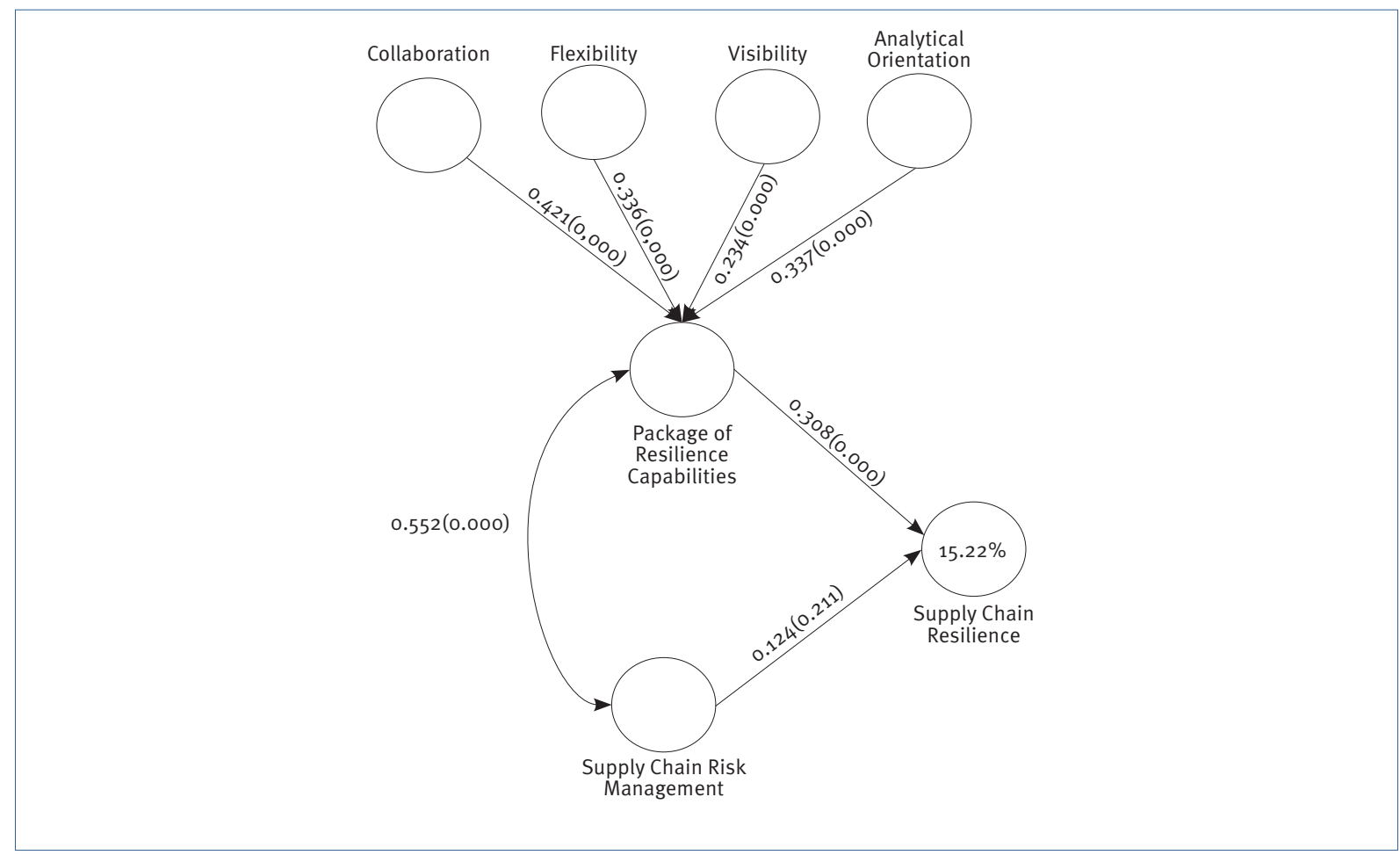




\section{DISCUSSION}

\section{Managerial implications}

In practice, the results indicate that supply chain members should seek greater collaboration, visibility, flexibility, and analytical orientation in their supply chain processes if they wish to avoid the collapse of their operations when their supply chains are disrupted. We found that SCRM has a synergistic effect with resilience capabilities, but does not directly affect resilience itself. In other words, our argument is that supply chain risk management helps with prevention, but when it comes to a disruptive event, the remedy is found in the resilience capabilities' package, so supply chain managers need to ensure the robustness of their resilience capabilities. As resilience capabilities work together, an analysis of the level of the capabilities may show managers where to invest to ensure better resilience results.

To improve their visibility, organizations must invest in obtaining information about events, resources, production, process status, and future partners' plans (Caridi et al., 2010). Promoting collaboration between chain members, therefore, plays a fundamental role in achieving better results in terms of visibility (Holcomb, Ponomarov, \& Manrodt, 2011). The information obtained, however, must be useful, reliable, and received at the right time for decision-making (Barratt \& Oke, 2007; Brandon-Jones et al., 2014; Caridi, Moretto, Perego, \& Tumino, 2014; Oliveira \& Handfield, 2019).

Chains require that any information generated and obtained through collaboration between members be processed to achieve greater visibility, transparency, and real-time information (Oliveira \& Handfield, 2019; Zhu, Song, Hazen, Lee, \& Cegielski, 2016). We suggest, therefore, investing in information systems and technologies that enable proper information sharing and processing (Barratt \& Oke, 2007; Brandon-Jones et al., 2014; Caridi et al., 2014). As Kirchoff (2019) pointed out, "new technologies such as blockchain show a promise of better connect members of the supply chain and improve trust and transparency" (p.1) .

To improve collaboration, the focal company and its main customers and suppliers, must develop key factors, such as information exchange, trust, personal interactions, and joint planning (Kohli \& Jensen, 2010). Investment in technologies like those mentioned above might promote a greater level of chain integration, resulting in new opportunities for process improvement (Bronzo et al., 2013; Vanpoucke, Vereecke, \& Wetzels, 2014).

An analytical orientation facilitates the identification of changes in consumer behavior, opportunities for developing new products and new markets, and for absorbing external information (Teo, Nishant, \& Koh, 2016); in other words, greater flexibility. Aiming to improve their analytical orientation, chains should have the right decision support systems available at the right time, so qualified people can take advantage of the data produced (Davenport, Harris, Long, \& Jacobson, 2001; Laursen \& Thorlund, 2010). As Srinivasan and Swink (2018) pointed out, visibility and flexibility are complementary to analytics. Visibility promotes data for analytics, and the insights generated through analytics can only be put into practice properly if supply chain members have some degree of flexibility (Srinivasan \& Swink, 2018).

Since not all risks can be avoided, the research results do not imply that organizations should adopt a reactive stance to risk management, but they should point out solutions when events that have not been identified or adequately managed result in interruptions. Therefore, the risk management steps of (1) risk identification, (2) risk assessment, (3) risk control, 4) risk monitoring (Aqlan \& Lam, 2015; Tummala \& Schoenherr, 2011) are still vital to the survival and prosperity of supply chains. 


\section{Theoretical implications}

First, this study questioned the components of resilience, both theoretically and empirically. It empirically verified that supply chain members effectively prevent disruptions by managing risks, but they are not necessarily effective in independently recovering (resilience), as this study did not confirm the direct impact of SCRM on resilience. Therefore, the research contests the assertion that prevention, which theoretically relates to risk management, is not a dimension or a direct antecedent of supply chain resilience.

Furthermore, all of the most researched resilience capabilities were grouped into a package, since it is the combination of these capabilities that increases supply chain resilience. To the best of our knowledge, this has never been tested in literature until now. As we argued in the managerial implications, one capability is complementary to another, meaning that the full power of their development can only be achieved by developing them together.

This study's primary theoretical contribution involved developing and testing a theoretical model that includes analytical orientation as a resilience capability component of the resilient capabilities' package. This also has never been previously tested and, along with the other proposed capabilities, proved to be capable of explaining the supply chain resilience of manufacturing industries in southeastern Brazil. The individual impact of analytics on supply chain resilience has been previously shown in Dubey et al. (2019) and Singh and Singh (2019).

\section{CONCLUSIONS}

Based on the fact that supply chain risks and uncertainties can cause devastating disruptions to their members, this article aimed to present empirical evidence that can be used to drive efforts in a quest for improving supply chain resilience when facing disruptive events and global threats, such as the COVID-19 pandemic. We argue that to be resilient, supply chains must exert their efforts to develop a resilience capabilities' package, which includes collaboration, flexibility, visibility, and an analytical orientation.

By way of an empirical study of manufacturing firms in Brazil, this paper addresses a relevant supply chain management topic. It analyzes the impact of a package of resilience capabilities on supply chain resilience, instead of the isolated influences of these capabilities. Using a statistical method, including confirmatory factor analysis and structural equation modeling, we were able to test the research hypotheses. First, this paper presents a resilience capabilities' package that was validated by the hierarchical model results, including analytical orientation as a part of this package. Second, based on structural model results, we were able to confirm the first hypothesis " $\mathrm{H}_{1}$ : The resilience capabilities package has a positive impact on supply chain resilience" and "H3: A positive, mutual relationship exists between the resilience capabilities' package and supply chain risk management", and reject "H2: Supply chain risk management has a positive impact on supply chain resilience". The hypothesis results enabled to validate the proposed theorical model by an empirical test.

More specifically, our research provides a better interpretation of the supply chain resilience construct, and verified whether collaboration, flexibility, visibility, and analytical orientation are components of a resilience capabilities' package; it confirmed not only if this package impacts SCRM, but also if SCRM has an impact on the resilience capabilities' package. The results indicated that this package results in an easier and quicker way for supply chains to return to their previous condition after disruptions occur, or to evolve to a better, more desirable condition; in other words, collaborative, flexible, visible, and analytical supply chains are more resilient. It is this 
set of capabilities that makes chains more resilient, because the absence of one of these capabilities leads to a sub-optimization of the resilience result.

Our findings suggest that SCRM does not directly affect supply chain resilience. One theoretical explanation for this finding is that prevention does not remedy disruptions in a company that needs help to recover. Alternatively, organizations could jointly develop capabilities such as collaboration, visibility, flexibility, and analytical orientation, but since other studies suggest prevention as a dimension of supply chain resilience (Pavlov et al., 2018; Rajesh, 2017; Sáenz et al., 2018), this is theoretically doubtful. Consequently, a question arises from this study: Can prevention make firms more resilient, or is prevention a necessary, but insufficient condition for resilience?

Since we are currently going through an unprecedented global interruption connected with the COVID-19, future studies can investigate what additional capabilities might have helped minimize the impact of the virus in supply chains; in other words, what are the differences between the supply chains that were more or less impacted? Future studies might also look for lessons in the memory of supply chains, which can be used to avoid a future global crisis, or to recover from one faster.

Testing the model outside Brazil in different cultures and settings would also be worth considering. It might also be interesting to investigate how the structure of the SC impacts capabilities, e.g., how might collaboration be developed under different structural supply chain arrangements and its impact on resilience results.

Finally, we suggest that future research should investigate other capabilities that might also explain supply chain recovery, like safety and security. While supply chain "digitization" can result in countless benefits, as was argued throughout the article, this "digitization" also poses other risks for supply chains, and in this respect cybersecurity concerns are emerging as an increasingly relevant research topic in the field of supply chain resilience.

\section{ACKNOWLEDGEMENT}

This study was financed in part by the Coordenação de Aperfeiçoamento de Pessoal de Nível Superior - Brasil (CAPES) Finance Code 001.

\section{REFERENCES}

Ali, A., Mahfouz, A., \& Arisha, A. (2017). Analysing supply chain resilience: Integrating the constructs in a concept mapping framework via a systematic literature review. Supply Chain Management: An International Journal, 22(1), 16-39. doi: 10.1108/SCM-06-2016-0197

Alvarenga, M. Z., Oliveira, M. P. V. de, Zanquetto-Filho, H., \& Santos, W. R. dos. (2018a, December). Analytical supply chains: Are They more resilient? A model's proposition. Journal of Operations and Supply Chain Management, 11(2), 46-58. doi: 10.1266o/joscmv11n2p46-58

Alvarenga, M. Z., Oliveira, M. P. V. de, Zanquetto-Filho, H., \& Santos, W. R. dos. (2018b, December). Do analyticallyoriented supply chains better manage risks? Journal of Operations and Supply Chain Management, 11(2), 32-45. doi: 10.1266o/joscmv11n2p32-45
Ambulkar, S., Blackhurst, J., \& Grawe, S. (2015). Firm's resilience to supply chain disruptions: Scale development and empirical examination. Journal of Operations Management, 33-34, 111122. doi: 10.1016/j.jom.2014.11.002

Aqlan, F., \& Lam, S. S. (2015). A fuzzy-based integrated framework for supply chain risk assessment. International Journal of Production Economics, 161, 54-63. doi: 10.1016/j. ijpe.2014.11.013

Barbosa, M. W., \& Vicente, A. de la C. (2018). Managing supply chain resources with Big Data Analytics: A systematic review. International Journal of Logistics Research and Applications, 21(3), 177-200. doi: 10.1080/13675567.2017.1369501

Barratt, M. (2004). Understanding the meaning of collaboration in the supply chain. Supply Chain Management: An International Journal, 9(1), 30-42. doi: 10.1108/13598540410517566 
Barratt, M., \& Oke, A. (2007). Antecedents of supply chain visibility in retail supply chains: A resource-based theory perspective. Journal of Operations Management, 25(6), 1217 1233. doi: 10.1016/j.jom.2007.01.003

Brandon-Jones, E., Squire, B., Autry, C. W., \& Petersen, K. J. (2014). A contingent resource-based perspective of supply chain resilience and robustness. Journal of Supply Chain Management, 50(3), 55-73. doi: 10.1111/jscm.12050

Bronzo, M., Resende, P. T. V. de, Oliveira, M. P. V. de, McCormack, K. P., Sousa, P. R. de, \& Ferreira, R. L. (2013). Improving performance aligning business analytics with process orientation. International Journal of Information Management, 33(2), 300-307. doi: 10.1016/j.ijinfomgt.2012.11.011

Brusset, X., \& Teller, C. (2017). Supply chain capabilities, risks, and resilience. International Journal of Production Economics, 184, 59-68. doi: 10.1016/j.ijpe.2016.09.008

Cao, G., Duan, Y., \& Li, G. (2015). Linking business analytics to decision making effectiveness: A path model analysis. IEEE Transactions on Engineering Management, 62(3), 384-395. doi: 10.1109/TEM.2015.2441875

Cao, M., \& Zhang, Q. (2011). Supply chain collaboration: Impact on collaborative advantage and firm performance. Journal of Operations Management, 29(3), 163-180. doi: 10.1016/j. jom.2010.12.008

Caridi, M., Crippa, L., Perego, A., Sianesi, A., \& Tumino, A. (2010). Measuring visibility to improve supply chain performance: A quantitative approach. Benchmarking: An International Journal, 17(4), 593-615. doi: 10.1108/14635771011060602

Caridi, M., Moretto, A., Perego, A., \& Tumino, A. (2014). The benefits of supply chain visibility: A value assessment model. International Journal of Production Economics, 151, 1-19. doi: 10.1016/j.ijpe.2013.12.025

Caridi, M., Perego, A., \& Tumino, A. (2013). Measuring supply chain visibility in the apparel industry. Benchmarking: An International Journal, 20(1), 25-44. doi: 10.1108/14635771311299470

Ceryno, P. S., Scavarda, L. F., Klingebiel, K., \& Yüzgülec, G. (2013). Supply chain risk management: A content analysis approach. International Journal of Industrial Engineering and Management, 4(3), 141-150. Retrieved from http://www.iim. ftn.uns.ac.rs/images/journal/volume4/ijiem_vol4_no3_6. pdf

Chae, K., Olson, D., \& Sheu, C. (2014). The impact of supply chain analytics on operational performance: A resource-based view. International Journal of Production Research, 52(16), 4695 4710. doi: 10.1080/00207543.2013.861616

Christopher, M., \& Peck, H. (2004). Building the resilient supply chain. International Journal of Logistics Management, 15(2), 1-13. doi: 10.1108/09574090410700275

CNN (2019). Domino's stockpiling pizza ingredients ahead of "disorderly" Brexit. Retrieved from https://www.gnews.com. $\mathrm{au} /$ world/dominos-pizza-chains-stockpiling-ingredientsahead-brexit-crash-uk-news/48061c6b-obdc-4d58-83db50060923 dad 3
Colicchia, C., Dallari, F., \& Melacini, M. (2010). Increasing supply chain resilience in a global sourcing context. Production Planning \& Control, 21(7), 680-694. doi: 10.1080/09537280903551969

Colquitt, J. A., \& Zapata-Phelan, C. P. (2007). Trends in theory building and theory testing: A five-decade study of the Academy of Management Journal. Academy of Management Journal, 5o(6), 1281-1303. doi: 10.5465/amj.2007.28165855

Continuity Central.com, (2018). Gartner highlights 'digital twins' as an emerging organizational resilience tool. . Retrieved from https://www.continuitycentral.com/index.php/news/ resilience-news/3560-gartner-highlights-digital-twins-as-anemerging-organizational-resilience-tool

Cosgrove, E. (2020). Smithfield closes more plants as coronavirus cases grow among workers. Retrieved from https://www. supplychaindive.com/news/coronavirus-smithfield-plantclose/575903/

Daugherty, P. J., Richey, R. G., Roath, A. S., Min, S., Chen, H., Arndt, A. D., \& Genchev, S. E. (2006). Is collaboration paying off for firms? Business Horizons, 49(1), 61-70. doi: 10.1016/j. bushor.2005.06.002

Davenport, T. H., Harris, J. G., Long, D. W. De, \& Jacobson, A. L. (2001). Data to knowledge to results: Building an analytics capability. California Management Review, 43(2), 117-138. doi: $10.2307 / 41166078$

Dubey, R., Gunasekaran, A., Childe, S. J., Fosso Wamba, S., Roubaud, D., \& Foropon, C. (2019). Empirical investigation of data analytics capability and organizational flexibility as complements to supply chain resilience. International Journal of Production Research, 59(1), 1-19. doi: 10.1080/00207543.2019.1582820

Durach, C. F., \& Machuca, J. A. D. (2018). A matter of perspective: The role of interpersonal relationships in supply chain risk management. International Journal of Operations \& Production Management, 38(10), 1866-1887. doi: 10.1108/ IJOPM-03-2017-0157

Graeml, A. R., Peinado, J. (2014). O efeito das capacidades logísticas na construção de resiliência da cadeia de suprimentos. Revista de Administração, 49(4), 642-655. doi: $10.5700 /$ rausp1174

Hair, J. F., Anderson, R. E., Tatham, R. L., Black, W. C., Babin, B. J., \& Anderson, R. E. (2009). Multivariate data analysis: Pearson Education Ltd. (7th ed.). Upper Saddle River, NJ: Prentice Hall. doi: 10.1016/j.ijpharm.2011.02.019

Hair, J. F., Jr., Hult, G. T. M., Ringle, C. M., \& Sarstedt, M. (2017). A primer on Partial Least Squares Structural Equation Modeling (PLS-SEM). In T. Oaks (Ed.), Handbook of market research (2nd ed., Vol. 26 1-374). Thousand Oaks, Los Angeles: Sage. doi: 10.1007/978-3-319-05542-8_15-1

Hallikas, J., Karvonen, I., Pulkkinen, U., Virolainen, V. M., \& Tuominen, M. (2004). Risk management processes in supplier networks. International Journal of Production Economics, 9o(1), 47-58. doi: 10.1016/j.ijpe.2004.02.007 
Hernandez, D. F., \& Haddud, A. (2018). Value creation via supply chain risk management in global fashion organizations outsourcing production to China. Journal of Global Operations and Strategic Sourcing, 11(2), 250-272. doi: 10.1108/ JGOSS-09-2017-0037

Holcomb, M. C., Ponomarov, S. Y., \& Manrodt, K. B. (2011). The relationship of supply chain visibility to firm performance. Supply Chain Forum: An International Journal, 12(2), 32-45. doi: 10.1080/16258312.2011.11517258

Ittmann, H. W. (2015). The impact of big data and business analytics on supply chain management. Journal of Transport and Supply Chain Management, 9(1), 1-9. doi: 10.4102/jtscm.v9i1.165

Ivanov, D., Dolgui, A., Das, A., \& Sokolov, B. (2019). Digital supply chain twins: Managing the ripple effect, resilience, and disruption risks by data-driven optimization, simulation, and visibility. In $1 \mathrm{ed}$. Handbook of ripple effects in the supply chain (pp. 309-332). Gewerbestrasse, Springer. https://doi. org/10.1007/978-3-030-14302-2_15

Jüttner, U., \& Maklan, S. (2011). Supply chain resilience in the global financial crisis: An empirical study. Supply Chain Management: An International Journal, 16(4), 246-259. doi: 10.1108/13598541111139062

Jüttner, U., Peck, H., \& Christopher, M. (2003). Supply chain risk management: Outlining an agenda for future research. International Journal of Logistics: Research and Applications, 6(4), 197-210. doi: 10.1080/13675560310001627016

Kirchoff, J.. (2019). How to assess risks in a globalized supply chain. Retrieved from https://www.supplychaindive.com/ news/assess-risks-globalized-supply-chain/568971/

Kohli, A. S., \& Jensen, J. B. (2010). Assessing effectiveness of supply chain collaboration: An empirical study. Supply Chain Forum: An International Journal, 11(2), 2-16. doi: 10.1080/16258312.2010.11517228

Kumar, S., \& Anbanandam, R. (2019). Impact of risk management culture on supply chain resilience: An empirical study from Indian manufacturing industry. Proceedings of the Institution of Mechanical Engineers, Part O: Journal of Risk and Reliability, 234(2), 246-259. doi: 10.1177/1748006X19886718

Kwak, D.-W., Seo, Y.-J., \& Mason, R. (2018). Investigating the relationship between supply chain innovation, risk management capabilities and competitive advantage in global supply chains. International Journal of Operations \& Production Management, 38(1), 2-21. doi: 10.1108/ IJOPM-06-2015-0390

Lacerda, R. T. de O., Ensslin, L., \& Ensslin, S. R. (2012). Uma análise bibliométrica da literatura sobre estratégia e avaliação de desempenho. Gestão \& Produção, 19(1), 59-78. doi: $10.1590 /$ s0104-530x2012000100005

Ladeira, M. B., Resende, P. T. V. de, Oliveira, M. P. V. de, McCormack, K., Sousa, P. R. de, \& Ferreira, R. L. (2016). Os efeitos da abordagem analítica e da gestão orientada para processos sobre o desempenho organizacional de micro e pequenas empresas brasileiras dos setores da indústria e de serviços. Gestão \& Produção, 23(32), 486-502. doi: 10.159o/ S0104-530X2012000200012
Laursen, G. H. N., \& Thorlund, J. (2010). Business analytics for managers. Hoboken, NJ: John Wiley \& Sons, Inc. https://doi. org/10.1002/9781118983812

Li, G., Fan, H., Lee, P. K. C., \& Cheng, T. C. E. (2015). Joint supply chain risk management: An agency and collaboration perspective. International Journal of Production Economics, 164, 83-94. doi: 10.1016/j.ijpe.2015.02.021

Lopez, E. (2018). H\&M's turnaround runs through its supply chain. Retrieved from https://www.supplychaindive.com/ news/HM-turnaround-runs-through-supply-chain/520495/

Mandal, S., Sarathy, R., Korasiga, V. R., Bhattacharya, S., \& Dastidar, S. G. (2016). Achieving supply chain resilience: The contribution of logistics and supply chain capabilities. International Journal of Disaster Resilience in the Built Environment, 7(5), 544-562. doi: 10.1108/IJDRBE-04-2016-0010

Marafon, A. D., Ensslin, L., Lacerda, R. T. de O., \& Ensslin, S. R. (2015). The effectiveness of multi-criteria decision aid methodology: A case study of R\&D management. European Journal of Innovation Management, 18(1), 89-109. doi: 10.1108/EJIM-10-2013-0106

Merschmann, U., \& Thonemann, U. W. (2011). Supply chain flexibility, uncertainty and firm performance: An empirical analysis of German manufacturing firms. International Journal of Production Economics, 130(1), 43-53. doi: 10.1016/j. ijpe.2010.10.013

Namdar, J., Li, X., Sawhney, R., \& Pradhan, N. (2018). Supply chain resilience for single and multiple sourcing in the presence of disruption risks. International Journal of Production Research, 56(6), 2339-2360. doi: 10.1080/00207543.2017.1370149

Nooraie, S. V., \& Parast, M. M. (2015). A multi-objective approach to supply chain risk management: Integrating visibility with supply and demand risk. International Journal of Production Economics, 161, 192-200. doi: 10.1016/j.ijpe.2014.12.024

Norrman, A., \& Jansson, U. (2004). Ericsson's proactive supply chain risk management approach after a serious sub-supplier accident. International Journal of Physical Distribution \& Logistics Management, 34, 434-456. doi: 10.1108/09600030410545463

Ojha, R., Ghadge, A., Tiwari, M. K., \& Bititci, U. S. (2018). Bayesian network modelling for supply chain risk propagation. International Journal of Production Research, 56(17), 5795 5819. doi: 10.1080/00207543.2018.1467059

Oliveira, M. P. V. de, \& Handfield, R. (2019). Analytical foundations for development of real-time supply chain capabilities. International Journal of Production Research, 57(5), 1571-1589. doi: $10.1080 / 00207543.2018 .1493240$

Papadopoulos, T., Gunasekaran, A., Dubey, R., Altay, N., Childe, S. J., \& Fosso-Wamba, S. (2017). The role of Big Data in explaining disaster resilience in supply chains for sustainability. Journal of Cleaner Production, 142, 1108-1118. doi: 10.1016/j.jclepro.2016.03.059

Pavlov, A., Ivanov, D., Dolgui, A., \& Sokolov, B. (2018). Hybrid fuzzy-probabilistic approach to supply chain resilience assessment. IEEE Transactions on Engineering Management, 65(2), 303-315. doi: 10.1109/TEM.2017.2773574 
Pettit, T. J., Croxton, K. L., \& Fiksel, J. (2019). The evolution of resilience in supply chain management: A retrospective on ensuring supply chain resilience. Journal of Business Logistics, 40(1), 56-65. doi: $10.1111 /$ jbl.12202

Pettit, T. J., Fiksel, J., \& Croxton, K. L. (2010). Ensuring supply chain resilience: Development of a conceptual framework. Journal of Business Logistics, 31(1), 1-21. doi: 10.1002/j.2158 1592.2010.tboo125.x

Ponomarov, S. Y., \& Holcomb, M. C. (2009). Understanding the concept of supply chain resilience. The International Journal of Logistics Management, 20(1), 124-143. doi: 10.1108/09574090910954873

Prakash, S., Gautam, A., \& Soni, U. (2018). Supply chain risk management and quality: A case study and analysis of Indian automotive industry. International Journal of Intelligent Enterprise, 5(1/2), 194. doi: 10.1504/IJIE.2018.10012158

Rajesh, R. (2017). Technological capabilities and supply chain resilience of firms: A relational analysis using Total Interpretive Structural Modeling (TISM). Technological Forecasting and Social Change, 118, 161-169. doi: 10.1016/j.techfore.2017.02.017

Ribeiro, J. P., \& Barbosa-Povoa, A. (2018). Supply chain resilience: Definitions and quantitative modelling approaches - A literature review. Computers and Industrial Engineering, 115, 109-122. doi: 10.1016/j.cie.2017.11.006

Ringle, C. M., Wende, S., \& Becker, J.-M. (2014). SmartPLS 3.0. Hamburg, Germany: SmartPLS.

Roberson, C. M. (2019). Preparing for the unknown in your supply chain. Retrieved from https://www.forbes.com/ sites/cathymorrowroberson/2019/10/07/preparing-for-theunknown-in-your-supply-chain/\#385eod6339ff

Sáenz, M. J., Revilla, E., \& Acero, B. (2018). Aligning supply chain design for boosting resilience. Business Horizons, 61(3), 443 452 doi: 10.1016/j.bushor.2018.01.009

Sánchez, A., M. \& Pérez, M. P. (2005). Supply chain flexibility and firm performance. International Journal of Operations \& Production Management, 25(7), 681-700. doi: 10.1108/01443570510605090

Scavarda, L. F., Ceryno, P. S., Pires, S., \& Klingebiel, K. (2015). Supply chain resilience analysis: A Brazilian automotive case. RAE-Revista de Administração de Empresas, 55(3), 304-313. doi: 10.1590/So034-759020150306

Scholten, K., Schilder, S.. (2015). The role of collaboration in supply chain resilience. Supply Chain Management: An International Journal, 20(4), 471-484. doi: 10.1108/SCM-112014-0386

Scholten, K., Scott, P. S., \& Fynes, B. (2014). Mitigation processes: Antecedents for building supply chain resilience. Supply Chain Management: An International Journal, 19(2), 211-228. doi: 10.1108/SCM-06-2013-0191

SEBRAE (2016). Anuário do trabalho nos pequenos negócios. Retrieved from https://m.sebrae.com.br/Sebrae/Portal Sebrae/ Anexos/Anuario do Trabalho nos Pequenos Negócios 2016_.pdf
Sheffi, Y., \& Rice, J. B., Jr. (2005). A supply chain view of the resilient enterprise. MIT Sloan Management Review, 47(1), 41-48. Retrieved from https://sloanreview.mit.edu/article/asupply-chain-view-of-the-resilient-enterprise

Singh, N. P., \& Singh, S. (2019). Building supply chain risk resilience: Role of big data analytics in supply chain disruption mitigation. Benchmarking, 26(7), 2318-2342. doi: 10.1108/ BIJ-10-2018-0346

Sodhi, M. S., Son, B.-G., \& Tang, C. S. (2012). Researchers' perspectives on supply chain risk management. Production and Operations Management, 21(1), 1-13. doi:10.1111/j.19375956.2011.01251.x

Souza, G. C. (2014). Supply chain analytics. Business Horizons, 57(5), 595-605. doi: 10.1016/j.bushor.2014.06.004

Srinivasan, R., \& Swink, M. (2018). An investigation of visibility and flexibility as complements to supply chain analytics: An organizational information processing theory perspective. Production and Operations Management, 27(10), 1849-1867. doi: $10.1111 /$ poms.12746

Swafford, P. M., Ghosh, S., \& Murthy, N. (2006). The antecedents of supply chain agility of a firm: Scale development and model testing. Journal of Operations Management, 24(2), 170-188. doi: 10.1016/j.jom.2005.05.002

Swafford, P. M., Ghosh, S., \& Murthy, N. (2008). Achieving supply chain agility through IT integration and flexibility. International Journal of Production Economics, 116(2), 288 297. doi: 10.1016/j.ijpe.2008.09.002

Tang, O., \& Musa, S. N. (2011). Identifying risk issues and research advancements in supply chain risk management. International Journal of Production Economics, 133(1), 25-34. doi: 10.1016/j.ijpe.2010.06.013

Teo, T. S. H., Nishant, R., \& Koh, P. B. L. (2016). Do shareholders favor business analytics announcements? Journal of Strategic Information Systems, 25(4), 259-276. doi: 10.1016/j. jsis.2016.05.001

Thomé, A. M. T., Scavarda, L. F., Pires, S. R. I., Ceryno, P., \& Klingebiel, K. (2014). A multi-tier study on supply chain flexibility in the automotive industry. International Journal of Production Economics, 158, 91-105. doi: 10.1016/j. ijpe.2014.07.024

Trkman, P., Mccormack, K., Oliveira, M. P. V. de, \& Ladeira, M. B. (2010). The impact of business analytics on supply chain performance. Decision Support Systems, 49(3), 318-327. doi: 10.1016/j.dss.2010.03.007

Tummala, R., \& Schoenherr, T. (2011). Assessing and managing risks using the Supply Chain Risk Management Process (SCRMP). Supply Chain Management: An International Journal, 16(6), 474-483. doi: 10.1108/13598541111171165

Urciuoli, L., \& Hintsa, J. (2018). Improving supply chain risk management: Can additional data help? International Journal of Logistics Systems and Management, 30(2), 195. doi: 10.1504/IJLSM.2018.091962 
Vanpoucke, E., Vereecke, A., \& Wetzels, M. (2014). Developing supplier integration capabilities for sustainable competitive advantage: A dynamic capabilities approach.Journal of Operations Management, 32(7-8), 446-461. doi:10.1016/j.jom.2014.09.004

Wieland, A., \& Wallenburg, C. M. (2013). The influence of relational competencies on supply chain resilience: a relational view. International Journal of Physical Distribution \& Logistics Management, 43(4), 300-320. doi: 10.1108/ijpdlm-08-2012-0243

Wollenhaupt, G. (2019). In disaster response, health supply chain egos melt away. Retrieved from https://www.supplychaindive.com/ news/pharma-healthcare-disaster-response-hurricane/555942/

Wong, C. W. Y., Lirn, T. C., Yang, C. C., \& Shang, K. C. (2019). Supply chain and external conditions under which supply chain resilience pays: An organizational information processing theorization. International Journal of Production Economics, 226, 107610 doi: 10.1016/j.ijpe.2019.107610
Xu, S., Zhang, X., Feng, L., \& Yang, W. (2020). Disruption risks in supply chain management: A literature review based on bibliometric analysis. International Journal of Production Research, 59(11), 1-19. doi: 10.1080/00207543.2020.1717011

Zhu, S., Song, J., Hazen, B. T., Lee, K., \& Cegielski, C. (2016). How supply chain analytics enables operational supply chain transparency. International Journal of Physical Distribution \& Logistics Management, 48(1), 47-68. doi: 10.1108/ IJPDLM-11-2017-0341

Zineb, E., Brahim, B., \& Houdaifa, A. (2017). The impact of SCRM strategies on supply chain resilience: A quantitative study in the Moroccan manufacturing industry. International Journal of Supply Chain Management, 6(4), 70-75. Retrieved from http://ijis-scm. bsne.ch/ojs.excelingtech.co.uk/index.php/IJSCM/article/ download/1665/1665-6369-1-PB.pdf

\section{AUTHOR'S CONTRIBUTIONS}

Murilo Zamboni Alvarenga, Marcos Paulo Valadares de Oliveira and, Hélio Zanquetto Filho worked on the conceptualization and theoretical-methodological approach. The theoretical review has contributions from all authors. Data collection was coordinated by Marcos Paulo Valadares de Oliveira and Hélio Zanquetto Filho, and conducted by Murilo Zamboni Alvarenga. Data analysis included Murilo Zamboni Alvarenga and was assisted by Marcos Paulo Valadares de Oliveira and Hélio Zanquetto Filho. Murilo Zamboni Alvarenga, Marcos Paulo Valadares de Oliveira, Hélio Zanquetto Filho, Kevin C. Desouza, Paula Santos Ceryno worked together in the writing and final revision of the manuscript. 